\title{
Evaluasi Kebijakan: Pembangunan Desa melalui Energi Terbarukan (Studi Kasus Pembangkit Listrik Tenaga Surya di Desa Rawasari, Jambi)
}

\author{
Ahmad Rahma Wardhana ${ }^{1,2}$, Wening Hapsari Ma'rifatullah ${ }^{3}$ \\ ${ }^{1}$ Green Technology Manager Konsorsium Energi Mandiri dan Lestari (2016-2018) \\ 2Peneliti Pusat Studi Energi Universitas Gadjah Mada \\ ${ }^{3}$ Peneliti Lepas dengan Minat Studi Politik dan Pemerintahan; Analis Politik, Hukum, dan Keamanan pada Sekretariat Kabinet \\ Republik Indonesia \\ Correspondence e-mail: wardhanahmad@mail.ugm.ac.id
}

\begin{abstract}
Abstrak. Energi fosil (minyak bumi, batu bara, gas alam) adalah pedang bermata dua; di satu sisi tenaganya merupakan bahan bakar bagi pembangunan, namun di sisi lain residunya berkontribusi terhadap pemanasan global dan perubahan iklim. Energi terbarukan sebagai antitesis energi fosil adalah alternatif untuk menjawab problematika penggunaan energi fosil yang dianggap tidak ramah bagi bumi. Indonesia sebagai negara kepulauan memiliki kelimpahan sumber daya energi terbarukan yang siap dikembangkan potensinya dalam rangka melaksanakan kebijakan pembangunan yang sensitif lingkungan. Pada tahun 2016, LAKPESDAM-PBNU, Pusat Studi Energi UGM, Pusat Studi Ekonomi Kerakyatan UGM dan Center for Civic Engagement Studies berkesempatan mengembangkan sistem energi terbarukan di tiga lokasi, salah satunya adalah Desa Rawasari, di Jambi. Tulisan ini bertujuan memberikan evaluasi kebijakan pengembangan sistem energi tersebut yang berisi gambaran dinamika, peluang dan tantangan implementasi energi terbarukan dalam rangka mendorong diversifikasi dan kemandirian energi sebagai bagian mendukung pembangunan Indonesia dari desa.
\end{abstract}

Kata Kunci: Pembangunan Desa; Diversifikasi Energi; Kemandirian Energi; Energi Terbarukan

\begin{abstract}
Fossil energy (petroleum, coal, natural gas) is a double-edged sword; on the one hand its energy is fuel for development, but on the other hand, its residue contributes to global warming and climate change. Renewable energy as an antithesis of fossil energy is an alternative to answer the problem of the use of fossil energy that is considered unfriendly to the earth. Indonesia as an archipelagic country has an abundance of renewable energy resources that are ready to develop its potential to implement environmentally sensitive development policies. In 2016, LAKPESDAM-PBNU, Center for Energy Studies UGM, Center for Economic Democratic Studies, and Center for Civic Engagement Studies had the opportunity to develop renewable energy systems in three locations, one of which is Rawasari Village, in Jambi. This paper aims to provide an evaluation of the energy system development policy which contains an overview of the dynamics, opportunities, and challenges of the implementation of renewable energy to encourage energy diversification and independence as part of supporting Indonesia's development from the villages.
\end{abstract}

Keywords: Village Development; Energy Diversification; Energy Independence; Renewable energy

\section{PENDAHULUAN}

Energi terbarukan didefinisikan sebagai energi yang berasal dari sumber yang terbarukan secara alami dan berkelanjutan, dengan laju produksi lebih cepat dibandingkan laju konsumsinya, seperti sinar matahari, angin, hujan, pasang-surut, gelombang, dan panas bumi. Energi terbarukan memiliki empat fungsi khas, yaitu menghasilkan energi untuk listrik, pendingin atau pemanas air dan udara, transportasi, dan jasa energi untuk wilayah terpencil (Ellaban dkk, 2014; REN21, 2010; iea.org, 2016; IRENA, 2009). Kesadaran penggunaan energi terbarukan yang meningkat dewasa ini menjadi penting sebagai usaha mitigasi perubahan iklim karena dinilai lebih ramah lingkungan dibandingkan sumber energi lain.

Data tahun 2016 menunjukkan bahwa energi terbarukan -bersama beberapa sumber non-fosil lainmemasok sekitar $19 \%$ kebutuhan energi dunia, dengan kontribusi emisi karbon global sebesar $1 \%$. Sementara batu bara, dengan pasokan energinya yang mencapai $27 \%$, justru menyumbang $44 \%$ emisi karbon. Bandingkan pula dengan $32 \%$ pasokan minyak bumi yang menghasilkan 35\% emisi karbon dan $22 \%$ pasokan gas alam yang emisinya mencapai $20 \%$ dari emisi karbon global (IEA, 2018). Emisi gas rumah kaca $\left(\mathrm{CO}_{2}\right.$, $\mathrm{CH}_{4}$, dan $\mathrm{N}_{2} \mathrm{O}$ ) karena aktivitas manusia sangat dimungkinkan merupakan faktor dominan penyebab terjadinya pemanasan global dan perubahan iklim (IPCC, 2014).

Sementara itu, Indonesia dikaruniai bentang alam dan sosial yang menjadi faktor pendukung bagi pengembangan potensi energi terbarukan, seperti: 1) matahari bersinar sepanjang tahun; 2) tidak mengalami musim dingin sehingga tidak ada permintaan energi yang besar dalam bentuk panas; 3) wilayah laut yang luas sebagai sumber pengembangan energi kelautan (pasang-surut atau gelombang); 4) terdapat kawasan perkotaan besar yang padat sebagai sumber energi dari sampah dan limbah; 5) negara dengan biodiversitas terbesar ketiga di dunia sebagai sumber diversifikasi energi berbasis makhluk hidup (biofuel berbasis ekstraksi tumbuhan atau ganggang); 6) memiliki gunung berapi dan hutan, sebagai potensi energi panas bumi, biomassa, serta fungsi konservasi air dan biodiversitas; 7) negara dengan pantai terpanjang ketiga di dunia sekaligus memiliki pegunungan sebagai sumber energi angin; 8) sungai, pegunungan, dan saluran irigasi sebagai sumber energi air (pikohidro, mikrohidro, minihidro, Pembangkit Listrik Tenaga Air); 9) banyaknya wilayah kepulauan sebagai potensi pengembangan energi dengan sumber daya terbarukan setempat; serta 10) konsumsi protein hewani yang besar (unggas, sapi, kambing, babi), sebagai sumber biogas (diadopsi dari Budiarto, dkk, 2017). 


\section{METODE PENELITIAN}

Tulisan ini merupakan hasil evaluasi terhadap program implementasi sistem pembangkit listrik energi terbarukan jenis energi surya (pembangkit listrik tenaga surya / PLTS) yang menitikberatkan pada penerapan operasional sesuai dengan spesifikasi teknisnya dan selaras dengan rencana pengembangan fungsinya. Lebih jauh, penelitian dilangsungkan dengan mengajukan pertanyaan, seperti misalnya: 1) apakah PLTS masih berfungsi dengan baik sesuai dengan peruntukannya pasca pelaksanaan proyek; 2) adakah kendala teknis dalam mengoperasikan PLTS; 3) apakah bisnis berbasis PLTS dapat berlangsung sebagaimana desain business plan; dan 4) apakah skema pembiayaan pemeliharaan dan penggantian komponen PLTS berbasis bisnis energi terbarukan dan subsidi Desa dapat berjalan.

Pengambilan data dilakukan di lokasi pembangunan PLTS, yaitu Desa Rawasari, Kecamatan Berbak, Kabupaten Tanjung Jabung Timur, Provinsi Jambi, sejak bulan September 2016 sampai dengan Februari 2018 serta wawancara maupun interaksi virtual sejak Maret sampai dengan Desember 2018.

\section{HASIL DAN PEMBAHASAN Urgensitas Energi}

Isu energi mulai dibahas sejak munculnya kesadaran tentang pentingnya panas dari api yang diantaranya berfungsi untuk mengolah pangan dan menghangatkan badan. Pengenalan pada energi panas terus menerus berkembang mengikuti peradaban manusia, dengan penemuan komoditas minyak, gas, batu bara, dan kemudian konversinya ke energi listrik. Kini, terminologi energi tak lagi berkaitan dengan peruntukan pangan saja, tetapi identik pula dengan transportasi (panas), industri (listrik dan panas), komersial (listrik), rumah tangga (listrik dan panas), dan pelayanan publik (listrik) (Wardhana dkk, 2018). Pemanfaatan energi dimaknai sebagai sebuah layanan, yakni manfaat yang dihasilkan oleh pembawa energi untuk kepentingan hidup manusia. Mengolah bahan pangan, memasak, fasilitas pendidikan, kesehatan, bisnis, telekomunikasi, hiburan, dan lain sebagainya, adalah ilustrasi bagaimana energi dapat melayani manusia (Modi dkk, 2005).

Pada tahun 2002, dalam World Summit on Sustainable Development yang diselenggarakan PBB, sektor energi menjadi salah satu syarat utama yang harus dipenuhi dalam upaya pengentasan kemiskinan. Pertemuan tersebut menekankan pentingnya energi sebagai stimulan untuk meningkatkan produktivitas usaha dan aktivitas ekonomi, menciptakan lapangan kerja dan sumber pendapatan baru, serta memperbaiki kualitas hidup umat manusia, terutama ibu dan anakanak. Sampai saat ini, isu pemanfaatan energi dalam konteks mengurangi kemiskinan tersebut masih terus relevan, termasuk di Indonesia (Ghazali dkk, 2017).

Dengan kata lain, sektor energi memainkan peran signifikan dalam pembangunan untuk mencapai kesejahteraan yang perlu dijamin ketersediannya oleh negara. Tanggung jawab tersebut merupakan aktualisasi konsep negara kesejahteraan dalam arti negara agar: 1) mengelola kekayaan bersama untuk sebesar-besarnya kemakmuran rakyat, 2) mencegah penguasaan kekayaan bersama oleh modal perseorangan asing maupun lokal yang melemahkan sendi ekonomi kolektif, 3) mengembangkan semangat tolong menolong dalam berbagai bentuk badan usaha serta memperkuat badan usaha koperasi sebagai emansipasi golongan ekonomi kecil dan menengah (Latif, 2011). Keberadaan Badan Usaha Milik Negara (BUMN) sebagai pelaku utama dalam produksi dan distribusi energi nasional seperti PT Pertamina (Persero), PT Perusahaan Gas Negara Tbk, dan PT Perusahaan Listrik Negara (PLN) (Persero) merupakan salah satu bentuk kesungguhan negara dalam menjamin terpenuhinya kebutuhan masyarakat kepada energi.

\section{Kebijakan Energi Nasional}

Kebijakan Energi Nasional Indonesia, sebagaimana dijelaskan dalam Peraturan Pemerintah Republik Indonesia No. 79 Tahun 2014 (PP RI No. 79/2014), memiliki tujuan berupa kemandirian energi dan ketahanan energi yang dicapai dengan mewujudkan 8 hal, yang empat diantaranya adalah 1) pengelolaan sumber daya energi secara optimal, terpadu, dan berkelanjutan, 2) akses untuk masyarakat terhadap energi secara adil dan merata, 3) terciptanya lapangan kerja, serta 4) terjaganya fungsi lingkungan hidup. Secara spesifik, PP RI No. 79/2014 juga menargetkan beberapa hal penting seperti tercapainya rasio elektrifikasi sebesar $85 \%$ pada tahun 2015 dan mendekati $100 \%$ pada tahun 2020 serta peran energi baru dan terbarukan dalam bauran energi primer yang mencapai $23 \%$ pada 2025 dan $31 \%$ pada 2050 (Pemerintah Republik Indonesia, 2014).

Di lapangan, rasio elektrifikasi nasional pada kuartal ketiga tahun 2018 yang baru mencapai 98,05\% (Kementerian ESDM RI, 2018) dan masih terdapat 2.391 desa yang belum berlistrik, dari total 82.190 desa (Dirjen Ketenagalistrikan Kementerian ESDM RI, 2018). Nilai rasio elektrifikasi $98,05 \%$ dapat dimaknai bahwa masih ada sekitar $1,95 \%$ rumah tangga atau setara jumlah 1.309.881 rumah tangga berdasarkan data Badan Pusat Statistik (2018), yang belum pernah menikmati listrik dari PLN. Sementara ditinjau dari sumber energinya, pemenuhan listrik nasional masih dikuasai oleh batu bara $(59,20 \%)$, gas alam $(22,30 \%)$, energi terbarukan $(12,32 \%)$, dan bahan bakar minyak, termasuk minyak berbasis bio $(6,18 \%)$ (Kementerian ESDM RI, 2018).

Beberapa sebab utama belum adanya listrik PLN di daerah-daerah tersebut adalah karena lokasi yang sulit terjangkau akibat kondisi alam atau infrastruktur jalan yang belum terbangun dengan baik, sehingga biaya pembangunan jaringan distribusi listrik menjadi mahal dan tidak layak secara finansial (Wardhana, 2018). Sebagai solusinya, negara melalui kementerian atau lembaga lain dan pemerintah daerah maupun BUMN, badan usaha swasta, atau lembaga donor, melakukan pembangunan infrastruktur energi terbarukan dengan berbagai skema, seperti Dana Alokasi Khusus dari Anggaran dan Pendapatan Belanja Negara (APBN), program beberapa kementerian terkait, dana CSR, atau menerima hibah luar negeri melalui lembaga donor. 


\section{Pengelolaan Energi Berbasis Masyarakat}

Di pulau yang besar dengan persebaran penduduk yang relatif merata seperti Jawa, Sumatera, atau Sulawesi, listrik dipenuhi dengan pembangkit besar serta jaringan distribusi yang panjang serta kompleks. Pengembangan sistem terpusat semacam ini pada mulanya merupakan ikhtiar untuk mencapai nilai ekonomis pembangkitan (Greenius dkk, 2010). Namun demikian, fenomena pemanasasn global dan perubahan iklim menunjukkan betapa lemahnya sistem terpusat tersebut. Greenius dkk (2010) menyatakan empat kelemahan utama pembangkitan energi fosil dengan sistem terpusat selain sebagai sumber emisi: 1) masyarakat yang pasif, 2) adanya jarak spasial dan psikologis yang signifikan antara sisi pembangkitan dan pemakaiannya, 3) tingginya potensi inefisiensi dan disrupsi, serta 4) stabilitas sistem yang rentan mendapatkan gangguan.

Alternatifnya, dibutuhkan sistem pengelolaan energi yang ramah lingkungan, tidak bergantung pada sistem terpusat, melibatkan masyarakat, dan memanfaatkan sumber energi setempat. Di dalam berbagai studi, pengembangan energi terbarukan yang memberdayakan masyarakat dikenal dengan Community Renewable Energy atau CRE (Greenius dkk, 2010). CRE tidak dapat dimaknai sebatas tentang pembangkitan energi lokal atau keterlibatan masyarakat saja, tetapi lebih merupakan sebuah proses dan pengaturan sosial yang mewujudkan pembangkitan energi lokal sebagai solusi yang berlanjut, dengan manfaat sosial dan ekonomi yang kembali kepada masyarakat sendiri (Walker dan Devine-Wrights' s, 2008 serta Walker dan Cass, 2007 dalam Greenius dkk, 2010). Sehingga terdapat tiga unsur utama dalam pengembangan $\mathrm{CRE}$ : 1) pembangkitan energi terbarukan, 2) keterlibatan masyarakat, 3) manfaat bagi masyarakat.

Lebih jauh, Shoaib dan Ariaratman (2016) merumuskan sedikitnya 8 dampak positif yang timbul dari pengembangan $\mathrm{CRE}$, yaitu: 1) menciptakan ikatan sosial, 2) menguatkan hubungan lintas komunitas, 3) membina rasa kepemilikan bersama dan tanggung jawab kolektif dalam menghadapi masalah yang dihadapi oleh komunitas, 4) membawa keuntungan ekonomi komunitas melalui keterlibatan tenaga kerja lokal, kerja sama dengan entitas bisnis setempat, penggunaan material dari wilayah terdekat, dan meningkatnya peran bank setempat, 5) meningkatkan ketahanan masyarakat melalui pengelolaan dana pembayaran jasa energi terbarukan, termasuk kemandirian dalam memilih prioritas investasi, 6) mengurangi emisi karbon dalam skala kecil, 7) meningkatkan kepedulian masyarakat pada isu-isu lingkungan, dan 8) meningkatkan kapasitas dan pengetahuan teknis masyarakat, karena sifat energi terbarukan yang sensitif pada kondisi lokal, sehingga membutuhkan keterlibatan masyarakat sejak perencanaan hingga pelaksanaan pembangunan (instalasi).

\section{Program Implementasi Energi}

Konsorsium Energi Mandiri dan Lestari (selanjutnya disebut KEMALA) adalah konsorsium yang terdiri dari empat lembaga, yakni Lembaga Kajian dan Pengembangan Sumber Daya Manusia Pengurus Besar Nahdlatul 'Ulama (LAKPESDAM-PBNU) sebagai pemimpin konsorsium, dan Pusat Studi Energi Universitas Gadjah Mada (PSE-UGM), Pusat Studi Ekonomi Kerakyatan UGM (PSEK-UGM), dan Center for Civic Engagement Studies (CCES) sebagai anggota konsorsium.

KEMALA turut berpartisipasi dalam memenuhi kebutuhan listrik di daerah terpencil melalui program Hibah Pengelolaan Sumber Daya Alam Berbasis Masyarakat (PSDABM) dari Millenium Challenge Account Indonesia (MCAI). Pendekatan yang dilakukan bukan hanya menerapkan sistem energi terbarukan berbasis energi surya, tetapi juga menyiapkan masyarakat, kelompok usaha dan pemerintah desa hingga kabupaten, serta membentuk kelembagaan, sehingga diharapkan dapat muncul sistem sosialinstitusional yang dapat mendukung beroperasinya pembangkit listrik tenaga surya (PLTS).

Rekayasa sosial-institusional ini dipandang penting mengingat karakteristik sistem PLTS yang membutuhkan pemeliharaan dan penggantian komponen PLTS secara rutin. Komponen utama PLTS sedikitnya terdiri dari panel surya yang usia teknisnya mencapai 20 tahun (dipasang ke arah matahari), serta pengontrol pengisian baterai, komponen baterai, dan inverter yang usia teknisnya hanya 5-6 tahun. Perbedaan usia yang signifikan ini berkonsekuensi pada perlunya penggantian pengontrol, baterai, dan inverter pada tahun ke-6, ke-12, dan ke-18 sejak PLTS pertama kali diinstalasi. Pada akhirnya PLTS menuntut adanya pemeliharaan secara berkala untuk menjamin sistem dapat beroperasi sesuai usia teknisnya dan tersedianya biaya untuk mengganti komponen pada tahun yang dimaksud.

Inilah perbedaan mendasar antara sistem listrik konvensional berbasis sistem PLN dengan sistem listrik CRE. Jika listrik PLN pembayarannya telah mencakup biaya pemeliharaan sumber energi, sistem distribusi, sekaligus sistem lokal di tingkat konsumen, maka sistem CRE memberikan kendali pemeliharaan di semua aspek, sepenuhnya kepada masyarakat. Begitu pula tentang penggantian komponen karena telah habis usianya ataupun karena insiden kerusakan, dalam sistem PLN dibebankan kepada PLN, sementara pada sistem CRE dibebankan kepada masyarakat.

Program implementasi energi terbarukan dalam bentuk CRE bukan hanya sekadar memasang sistem energi, bahkan pemasangan sistem adalah hal yang termudah dan tercepat dibandingkan tahapan lain, tetapi juga membutuhkan peningkatan kapasitas masyarakat dan lembaganya, desain sistem yang menyelesaikan persoalan teknis maupun non-teknis, termasuk sejauh mana dukungan pemerintah di berbagai tingkat, serta bagaimana interaksi antara manusia dan sistem tersebut dapat menjadi budaya yang mampu mendukung kehidupan PLTS. Kasus di Jawa Tengah nampaknya patut menjadi cermin penting dalam mengeksekusi program implementasi energi terbarukan: PLTS jenis Solar Home System (SHS, sistem di mana setiap rumah mendapatkan satu sistem PLTS yang tidak terkoneksi dengan rumah lainnya) sejak 2010-2017 telah terbangun 
2.566 unit, di mana pada 2017 hanya tinggal 56 unit saja yang masih menyala dengan baik (Rinanda, 2018).

\section{Desa Rawasari sebagai Lokasi Implementasi}

Desa Rawasari dipilih menjadi salah satu sasaran implementasi hibah karena latar belakang, seperti: 1) teknis, yakni belum tersentuh sistem listrik PLN, 2) sosial, yakni terdapat struktur Majelis Wakil Cabang Nahdlatul 'Ulama (MWC NU), 3) potensi sumber daya alam, yakni adanya komoditas lokal yang menjadi sumber pendapatan masyarakat.

Desa Rawasari (Gambar 1) secara fisik terbagi menjadi tiga kelompok pemukiman (dusun), yakni Blok $\mathrm{P}$ (79 rumah), Blok O (124 rumah), dan Blok N (21 rumah). Transportasi di masing-masing dusun dan antar-dusun menggunakan sepeda motor atau perahu motor tempel kecil. Kebutuhan sehari-hari masyarakat selain beras dapat dibeli dari toko kecil di masing-masing dusun, namun apabila menginginkan kebutuhan sekunder, masyarakat harus menyeberangkan sepeda motornya ke seberang sungai Batanghari untuk menuju ibukota kecamatan terdekat atau menggunakan perahu tersebut untuk berbelanja ke luar desa.

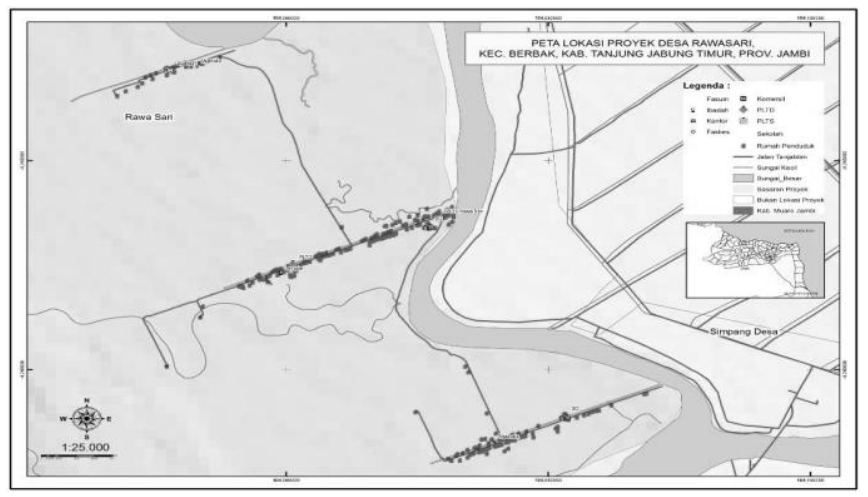

Gambar 1. Peta Desa Rawasari

Desain utama sistem teknis, sosial, dan institusional untuk mendukung sistem PLTS di Desa Rawasari ditunjukkan pada Gambar 2 dan Gambar 3. Gambar 2 menggambarkan dukungan PLTS untuk fasilitas publik, rumah tangga, maupun unit usaha. Sebelum hadirnya program, masyarakat menggunakan genset komunal atau genset pribadi untuk memenuhi kebutuhan listrik di malam hari. Setiap malam dibutuhkan sedikitnya 1-2 liter bahan bakar minyak jenis bensin premium atau solar untuk menyalakan genset. Listrik genset digunakan untuk menyalakan lampu, televisi, atau pemasak nasi listrik. Kasus di SD Blok P, kegiatan belajar dan mengajar (KBM) di siang hari tak bisa menggunakan sistem audio-visual, sementara kegiatan administrasi yang berkaitan dengan komputer dan pencetakan harus dilakukan malam hari di rumah guru atau menyeberang ke luar desa jika dibutuhkan di siang hari. Sedangkan SD-SMP di Blok O selama ini memanfaatkan energi dari Kantor Desa yang mempunyai PLTS sistem terpusat berdaya $15 \mathrm{~kW}$.

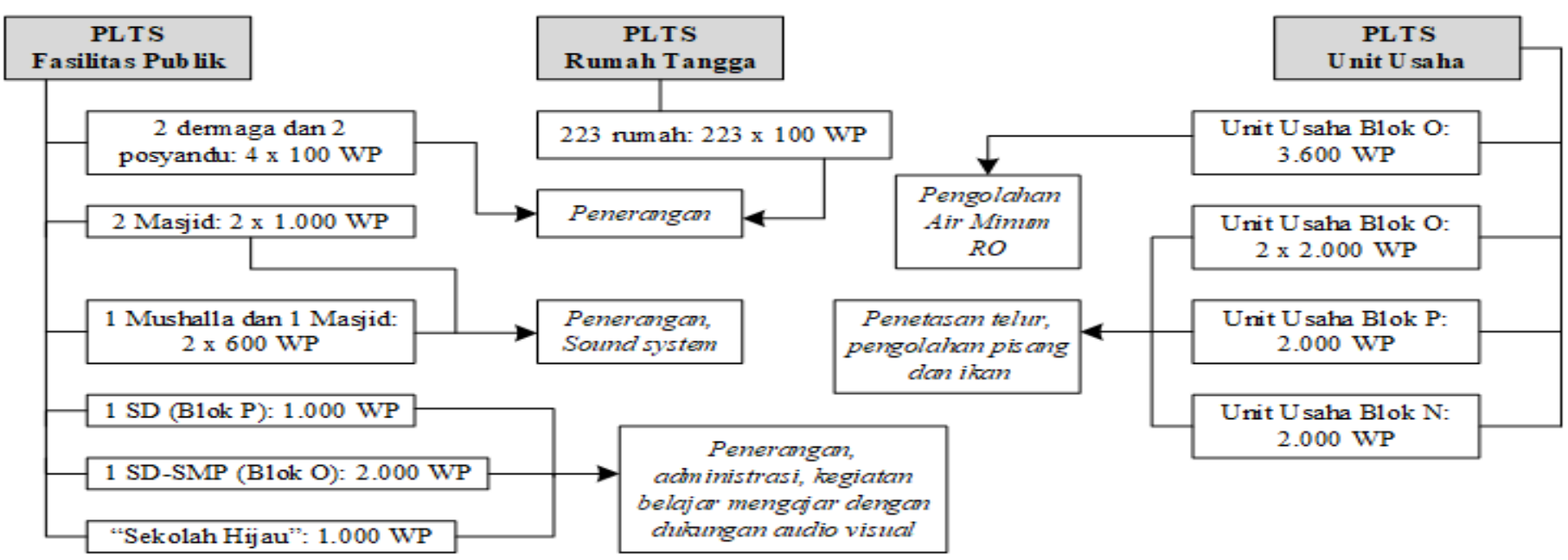

Gambar 2. Desain pemanfaatan PLTS Rawasari

Fasilitas publik masjid juga mendapatkan PLTS karena masyarakat Rawasari memiliki ritual agama rutin, baik siang, sore, maupun malam hari, oleh kelompok pemuda, kelompok ibu, maupun kelompok bapak. Sedangkan unit usaha dikelompokkan menjadi tiga, yakni usaha penetasan telur unggas, pengolahan makanan, utamanya produk pisang dan ikan, serta usaha pengolahan air minum. Ketiga usaha ini dipilih berdasarkan pilihan masyarakat. Untuk penetasan unggas misalnya, dipilih karena sering ada permintaan daging bebek dan ayam dari luar desa namun masyarakat Rawasari tidak mampu memenuhinya. Sementara usaha air minum dikembangkan karena kebutuhan air minum Rawasari dipenuhi dari luar desa melalui toko di tiap dusun, dengan harga $\mathrm{Rp} 8.000$ per galon air minum.

Bisnis pisang dan ikan menjadi komoditas menarik karena ketersediaannya yang melimpah secara berkala setiap tahunnya. Pisang lazimnya dijual apa adanya sebagai buah pisang, sedangkan ikan telah 
menjadi lauk utama masyarakat Rawasari. Hasil panen keduanya yang sering melebihi kebutuhan pokok dapat menjadi sumber pendapatan baru ketika diolah menjadi produk olahan seperti keripik pisang, bolu pisang, kerupuk ikan, bahkan bukan tidak mungkin produk tepung ikan dan tepung pisang yang memiliki daya jual tidak murah.

Sementara itu Gambar 3 merupakan ilustrasi alur kebutuhan pembiayaan PLTS dan bagaimana skema bisnis berbasis energi terbarukan, subsidi APB-Des, dan pembiayaan lain seperti corporate social responbility atau dana hibah penelitian dan pengabdian dapat menjadi support system. Tanda panah putus menunjukkan arah pembiayaaan yang berpeluang dimanfaatkan untuk mendukung pemeliharaan, perbaikan, dan pergantian komponen PLTS.

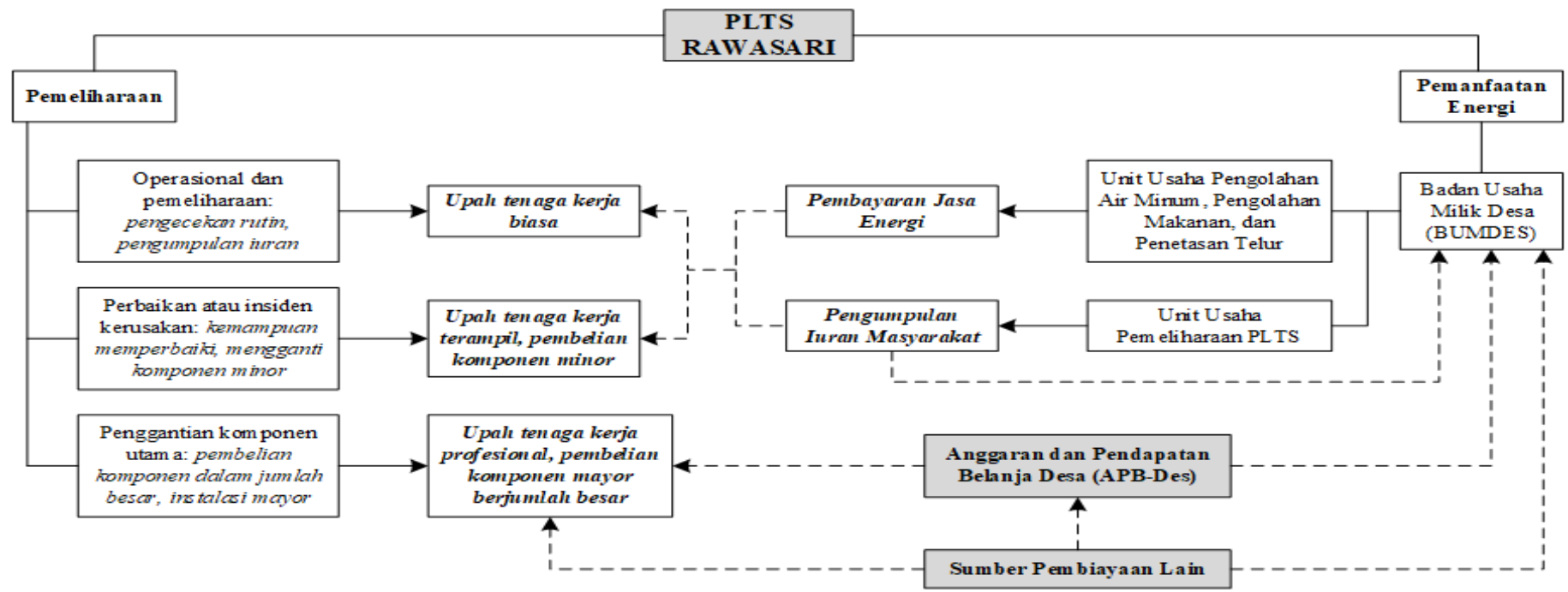

Gambar 3. Desain sistem pendukung pembiayaan pemeliharaan PLTS

Baik Gambar 2 maupun Gambar 3 membawa konsekuensi tentang bagaimana peningkatan kapasitas masyarakat diarahkan untuk dapat menjalankan desain tersebut sebisa mungkin mendekati ideal. Unit usaha penetasan telur misalnya, membutuhkan kepastian pasar, tentang kepada siapa unggas yang telah menetas dan tumbuh hingga usia pantas akan dijual. Hal yang sama berlaku pada produk olahan pisang dan ikan, kepada siapa produk tersebut dijual? Peningkatan kapasitas kemudian mengambil tema bagaimana menyusun business plan serta pemahaman mendasar bahwa bisnis baru keuntungannya belum tentu sesuai harapan, karena masih membutuhkan banyak eksperimen.

Pada kegiatan pengumpulan iuran dan pembayaran jasa energi diperlukan perhitungan yang tertib dan mendetail agar tidak terjadi keliru perhitungan. Khusus untuk unit usaha, pembayaran jasa energi harus menjadi bagian dari biaya produksi yang dihitung dalam harga jual produk akhir. Peningkatan kapasitas bukan lagi hanya soal rencana bisnis dan pengembangan pasar, tetapi juga tentang manajemen usaha serta reward and punishment bagi mereka yang berkenan membayar lebih atau justru sebaliknya, alpa membayar jasa energi, baik warga masyarakat maupun unit usaha. Dalam konteks masyarakat, langkah mendasar sejak awal sosialisasi program adalah bagaimana willingness to pay dapat muncul dari masyarakat sendiri. Dan iuran masyarakat yang sebenarnya adalah tabungan pembelian baterai di tahun ke-6 dan seterusnya, untuk sementara dapat dipergunakan oleh BUMDES untuk kegiatan usaha yang berisiko kecil, seperti membiayai unit usaha pengolahan makanan dan penetasan telur.
Sedangkan pembiayaan APB-Des, penyertaan modal ke BUMDES, maupun pembiayaan lain, membutuhkan pendampingan institusional, advokasi kepada masyarakat, serta bagaimana membentuk jejaring. Pembiayaan APB-Des dan penyertaan modal ke BUMDES akan dituangkan ke dalam Peraturan Desa lewat Musyawarah Desa. Sebuah Musyawarah Desa dapat berlangsung demokratis apabila komunikasi Pemerintah Desa dan warganya berjalan secara produktif.

Berdasarkan desain tersebut, pemasangan PLTS dilaksanakan pada bulan Desember 2017, setelah sejak September 2016-November 2017 dilakukan tahapan persiapan dan peningkatan kapasitas masyarakat Rawasari, yang di antaranya adalah: 1) penyatuan visi dan pembentukan kelompok relawan, 2) studi kelayakan teknis; 3) pengembangan desain teknis detail; 4) pelatihan tingkat dasar tentang nilai voluntarisme dan wawasan lingkungan; 5) pelatihan menengah tentang kelembagaan, peningkatan nilai tambah komoditas lokal, manajemen usaha, dan pengorganisasian; 6) pelatihan tingkat lanjut tentang teknis PLTS dan perencanaan bisnis; 7) pendampingan penyusunan kebijakan di tingkat desa, dan 8) pemasangan PLTS.

\section{Evaluasi Pascaprogram}

Pembangunan adalah isu yang selalu aktual dalam penyelenggaraan pemerintahan. Meskipun demikian, kultus bahwa pembangunan adalah domain negara sebenarnya sudah runtuh tiga dekade lalu ketika Bank Dunia mengemukakan tesis bahwa negara telah gagal menyediakan kebutuhan warganya di awal '90-an (Frederickson, 1980; Abrahamsen, 2004). Kegagalan tersebut mengubah cara pandang para scholar dan 
pegiat pembangunan terhadap negara dengan kemunculan istilah "governance" atau governability" yang mengisyaratkan bahwa proses pengambilan kebijakan bukanlah monopoli elit pemerintah, melainkan hasil interaksi antar pemangku kepentingan (Brunsson, 1994; Howlett \& Ramesh, 1998; Pierre \& Peters, 2000). Hari ini gairah pembangunan untuk menyediakan kebutuhan dasar tidak hanya menjadi milik negara, melainkan seluruh pemangku kepentingan. Kelompok bisnis boleh membangun atas nama tanggung jawab sosial. Kelompok masyarakat sipil menjangkau lokasi yang tidak terjamah negara atas nama membangun keberadaban. Kemala mencoba memainkan peran sebagai katalis bagi negara dengan menjangkau lokasi yang tak mampu terjamah pemerintah untuk membangun sistem energi terbarukan berbasis partisipasi masyarakat.

Evaluasi terhadap proyek tersebut bermuara pada penemuan data menarik terkait pembangunan dan implikasinya terhadap struktur sosial-ekonomi masyarakat Desa Rawasari yang menjadi subjek pembangunan. Secara teknis, seluruh sistem PLTS masih beroperasi secara normal tanpa ada kerusakan yang berarti. Memang terjadi kerusakan kecil, namun masih dapat ditangani secara teknis oleh pengelola di Rawasari, sebagai hasil dari pelatihan dan pendampingan pada masa instalasi PLTS, tepat setahun yang lalu.

Terjadi perubahan konsumsi energi di Rawasari pasca-instalasi PLTS. Bahkan dapat dikatakan terdapat pengurangan signifikan konsumsi bahan bakar minyak di Rawasari. Kebutuhan pokok masyarakat Rawasari di malam hari adalah penerangan untuk aktifitas malam hari, baik di tingkat rumah tangga (memasak, makan, belajar, dan kegiatan rumah tangga lainnya) maupun di tingkat komunitas (kegiatan rutin seperti arisan, pengajian, ibadah di masjid atau mushalla). Beberapa masyarakat merasa penerangan tersebut sudah cukup, sehingga tidak lagi setiap malam menyalakan genset untuk menonton televisi. Bukan tidak mungkin, dampak positif sebagaimana disampaikan Shoaib dan Ariaratman (2016) telah terjadi di Rawasari: menciptakan ikatan sosial, menguatkan hubungan lintas komunitas, dan membina rasa kepemilikan bersama dan tanggung jawab kolektif dalam menghadapi masalah yang dihadapi oleh komunitas. Lebih dari itu, pengurangan emisi karbon sebagai salah satu dampak utama penggunaan energi terbarukan, secara riil telah terwujud Rawasari.

\section{Pembangunan Berbasis Konteks}

Pembangunan yang dihadirkan ke desa perlu memperhatikan konteks desa itu sendiri agar berjalan optimal. Maka dari itu, intervensi negara untuk menghadirkan pembangunan di desa dalam rangka memenuhi kebutuhan dasar perlu mempertimbangkan tiga cara pandang tentang desa agar interaksi berjalan secara "good governance", seimbang dan tidak condong pada satu karakter wajah.

Pertama, desa merupakan bagian dari masyarakat sipil yang identik dengan pola interaksi komunal antar warga karena persamaan identitas, perasaan senasib sepenanggungan. Desa memiliki tradisi lokal dan hukum adat dalam proses pengambilan keputusan yang bersifat otonom (Santoso ed, 2003). Kedua, desa adalah sumber kehidupan yang mampu menyediakan kebutuan dasar bagi manusia. Desa memiliki lahan yang subur, sungai yang mengalir, tenaga kerja yang murah, lokasi yang menarik hati investor. Pada level ini desa adalah ruang transaksional yang membuat roda perekonomian berjalan. Apabila prosesnya dikelola dengan baik maka akan mendatangkan kesejahteraan, namun ketika dikooptasi oleh sekelompok elit maka akan menghasilkan pola rente yang merugikan sebagian warga desa. Ketiga, pemaknaan desa sebagai bagian dari hirarki pemerintahan yang membuat desa terikat dan tunduk pada aturan main di atasnya (negara) (Mas'oed, 1997).

Pembangunan yang terpaku oleh aturan main top down dan dikuasai sekelompok elit saja tanpa memperhatikan kekhasan lokal berpotensi pada: pertama, rendahnya keterlibatan warga karena ketiadaan rasa memiliki terhadap produk pembangunan. Pembangunan yang bersifat top down akan melihat warga desa sebagai objek pembangunan-penikmat pembangunan-bukan subjek pembangunan. Kedua, munculnya monopoli dari kue pembangunan (Budiman, 1991). Hal ini dikarenakan distribusi terhadap akses pembangunan hanya dikuasai oleh sekelompok elit yang memiliki akses terhadap kekuasaan, seperti pamong desa, pemangku kepentingan, atau warga yang menguasai sumber daya desa.

Berdasarkan hasil evaluasi terhadap proyek pembangunan desa di Rawasari, tercatat bahwa muncul problematika yang diindikasi bersumber dari konflik warga komunal dengan elit desa sebagai penguasa sumber daya. Unit usaha pengolahan makanan dan penetasan telur dikelola oleh ibu-ibu yang nampak bersemangat di sepanjang periode pelatihan, pemasangan, dan penutupan program pada Februari 2018, saat ini tak lagi berjalan. Penyebabnya unik, yakni ketidakpercayaan para ibu pada institusi BUMDES sebagai induk unit usaha. Nampaknya hal ini disebabkan karena kontestasi politik pemilihan Kepala Desa pada tahun 2017, di mana kandidat yang memenangkan pilkades memiliki beberapa perbedaan pendapat dengan kelompok ibu tersebut. Boleh jadi pula, durasi pendampingan yang berlangsung di sepanjang 2017 sesungguhnya masih kurang, sehingga pemahaman tentang demokrasi di tingkat desa belum dipahami secara mendasar oleh masyarakat. Pemahaman demokrasi yang dimaksud adalah bagaimana Kepala Desa terpilih dapat merangkul masyarakat yang tak memilihnya dan di sisi lain kelompok yang tidak memilih Kepala Desa terpilih dapat secara legawa memperjuangkan kepentingannya melalui mekanisme demokrasi di tingkat desa.

Kemudian, berhentinya unit usaha penetasan telur dan pengolahan makanan berdampak pula pada bagian pembiayaan lainnya, seperti kesepakatan soal upah penarik iuran warga yang belum terselesaikan dengan baik. Akibatnya, sudah sekitar tiga bulan penarikan iuran tidak berjalan. Sesungguhnya ketika nilai-nilai partisipasi diimplementasikan dengan baik yang ditunjukkan dengan manajemen usaha yang tetap berjalan pasca pendampingan, di mana pencatatan iuran, 
penggunaannya sebagai modal tambahan untuk unit usaha lain, dan perputarannya terpantau serta terhitung, tak perlu ada kekhawatiran soal kurangnya pembiayaan untuk upah. Atau bukan tidak mungkin, desain pembiayaan tentang upah penarik iuran yang sedianya sebagai tambahan penghasilan selain menjadi petani atau pekerjaan pokok lain, belum ditangkap dengan baik oleh sebagian pengelola unit usaha pemeliharaan PLTS. Desain ideal dari skema ini yang paling mendasar adalah voluntarisme di bidang lingkungan dengan efek samping berupa penghasilan tambahan melalui keterlibatannya dalam mengelola PLTS.

Pembangunan yang cenderung komersil dan transaksional pada level yang ditoleransi sebenarnya bertujuan untuk meningkatkan rasa kepemilikan dan menjaga keberanjutan dalam rangka kemandirian sebagaimana yang didesain oleh Kemala dalam pengelolaan PLTS berbasis iuran. Kebijakan berpola transaksional ini menempatkan warganegara sebagai pelanggan berdasarkan kesepakatan untung-rugi. Karakter kebijakan bercorak komersial adalah mantra 'efektif, efisien, transparan, dan akuntabel' yang merupakan jargon masyarakat bisnis (Osborne \& Gaebler, 1995). Karakter ini dipinjam oleh Kemala agar pembangunan berjalan optimal.

Model pengelolaan PLTS yang transaksional berbasis partisipasi boleh jadi belum menunjukkan keberhasilan karena terkendala konflik komunal setempat. Namun pola transaksional tersebut berhasil di unit usaha air minum. Di musim kemarau, produksi air minum mencapai 50 galon per hari dan hanya separuhnya saja di musim penghujan. Unit usaha menjual produknya hanya kepada toko, baik di Blok $O$ maupun Blok P. Di Blok O, toko membeli air minum $\mathrm{Rp}$ 4.000 per galon, sementara di Blok $\mathrm{P}, \mathrm{Rp} 5.000,00$ per galon. Di Blok $P$ lebih mahal karena lokasi produksi air yang terdapat di Blok $\mathrm{O}$ membutuhkan biaya transportasi dengan perahu untuk diantarkan ke Blok P. Di rumah tangga, harga air berada di kisaran $\mathrm{Rp}$ 5.000,00-Rp. 6.000,00; harga yang cukup murah dibandingkan sebelumnya yang $\mathrm{Rp}$ 8.000,00. Wawancara kepada pengelola unit usaha air minum menggambarkan bagaimana kebutuhan pokok dan mendasar ini sebelumnya harus mengambil ke luar desa, menghabiskan waktu dan biaya tidak sedikit bagi toko, sekarang telah terpenuhi secara mandiri. Pengelola unit usaha berharap ada tambahan unit galon untuk meningkatkan volume produksi air.

Peneliti menyadari bahwa pola transaksional apabila tidak dikelola dengan baik akan menimbulkan: pertama, disparitas bagi warga minoritas yang tidak mampu mengakses pembangunan karena keterbatasan sumber daya, yang dikenal dengan istilah korban pembangunan-situasi yang dihindari oleh negara. Kedua, komersialisasi pembangunan yang berakibat pada perubahan pola interaksi warga desa yang komunal (gotong royong) menjadi profit oriented-jika tidak menguntungkan secara pribadi tidak akan terlibat dalam kerja pembangunan.

Di sinilah pembangunan partisipatif yang berjalan beriringan dengan pembangunan infrastruktur diperlukan dalam rangka mencapai kesejahteraan secara optimal. Kebijakan ini cenderung bersifat bottom-up yang memandang warganegara sebagai subjek kebijakan dengan mendorong partisipasi warga, mengakomodasi tradisi lokal dalam proses penyusunan kebijakan (Hikam, 1999). Metodenya beragam menyesuaikan konteks kewilayahan dan karakter warga: pertama, penyusunan aturan main yang jelas (demokratis) oleh elit desa yang memiliki legitimasi. Hal ini bertujuan agar pembangunan mendapat dukungan publik (warga desa), dan di sisi lain dia tidak dikooptasi elit desa. Kedua, pembangunan dengan pola transaksional dapat dilakukan selama disepakati oleh warga sebagai norma dan bertujuan untuk mempertahankan keberlanjutan pembangunan-dengan demikian pola transaksional ini harus diatur oleh regulasi agar tidak ada pihak yang menjadi korban pembangunan. Ketiga, pembangunan yang memperhatikan tradisi dan potensi desa sehingga warga mudah untuk mengadopsi dan beradaptasi dengan perubahan yang ada. Dengan demikian produk kebijakan cenderung berpola asimetris berdasarkan konteks dan kebutuhan subjek kebijakan.

\section{SIMPULAN}

Perubahan sumber energi ke sumber yang lebih ramah lingkungan tidak dapat begitu saja dilakukan tanpa melakukan perubahan ke seluruh sistem. PLTS dan sumber energi terbarukan lainnya memang berbeda dengan sistem energi fosil yang terpusat dan dapat memasok energi terus menerus. Perbedaannya, di sistem fosil-terpusat masyarakat tak dibebani dengan kerumitan pemeliharaan, sementara di sistem CRE masyarakat memiliki tanggung jawab penuh atas pemeliharaan tersebut, yang sebenarnya jauh lebih simpel dibandingkan sistem-fosil-terpusat.

Maka kemandirian energi berbasis sumber energi lokal oleh masyarakat setempat tidak hanya butuh grand design, tapi perlu diikuti dengan mendorong masyarakat memiliki kebutuhan-paradigma yang sama (sehingga mereka mau berpartisipasi) akan kemandirian energi untuk meningkatkan taraf hidupnya.

Lebih dari itu, masyarakat pedesaan dengan akar budaya yang kuat membutuhkan waktu yang tidak sebentar untuk membiasakan pola kehidupan baru, terutama dengan hadirnya sistem energi baru, pendekatan finansial baru, pemahaman lebih utuh tentang kerusakan lingkungan, dan bagaimana memperjuangkannya dengan elegan tanpa merendahkan diri sendiri maupun orang lain. Pola pendampingan yang sifatnya multitahun dengan mengambil dan memanfaatkan nilai-nilai kebijaksanaan lokal sebagai alat kampanye patut dipertimbangkan menjadi sebuah pendekatan baru. Dan terakhir, sungguh, kebijakan kemandirian energi akan percuma kalau hanya datang secara top-down, tanpa mempertimbangkan pendapat masyarakat sasaran. Studi kasus Rawasari menggambarkan pentingnya perpaduan pendekatan antara top-down dengan bottomup, agar tumbuh kesadaran voluntarisme yang diharapkan mengantar pada perjuangan mandiri dari masyarakat, untuk masyarakat, dan oleh masyarakat sendiri. 


\section{Ucapan Terima Kasih}

Terima kasih diucapkan kepada lembaga Millenium Challenge Account Indonesia di bawah koordinasi Kementerian Perencanaan Pembangunan Nasional Republik Indonesia, yang telah memberikan Hibah PSDABM kepada KEMALA. Terima kasih pula kepada seluruh manajemen KEMALA, baik kantor Yogyakarta, Jakarta, maupun Jambi, utamanya masyarakat Rawasari seluruhnya, atas kerja keras bersama yang akhirnya menjadi persaudaraan baru. Secara khusus doa kepada Allaah SWT disampaikan kepada Almarhum Mas Mohammad Bahrun Naser, salah satu personel manajemen KEMALA yang wafat beberapa waktu yang lalu: semoga Allaah SWT melimpahkan rahmat dan keberkahan kepada Mas Naser di alam barzakh hingga kelak di akhirat.

Bagian tulisan ini, utamanya tentang energi dan kondisi lapangan, telah ditulis dalam Tesis di Magister Teknologi untuk Pengembangan Berkelanjutan, Program Studi IImu Lingkungan, Sekolah Pascasarjana Universitas Gadjah Mada di bawah bimbingan Bapak Dr. Rachmawan Budiarto, M.T. dan Bapak Dr.Sc.Tech. Adhy Kurniawan, S.T., serta telah diuji oleh Bapak Dr.Eng. Mohammad Kholid Ridwan, S.T., M.Sc. dan Ibu Prof. Ambar Pertiwiningrum, M.Si., Ph.D., kepada keempatnya diucapkan terima kasih.

\section{DAFTAR PUSTAKA}

Abrahamsen, Rita. 2004. Sudut Gelap Kemajuan: Relasi Kuasa dalam Wacana Pembangunan. Yogyakarta: Lafadl Pustaka.

Badan Pusat Statistik. 2018. Statistik Indonesia 2018. Jakarta.

Budiarto R; Widhyarto DS; Prasetya A; Wardhana AR; Hidayat JJ. 2017. Energi Surya untuk Komunitas Meningkatkan Produktivitas Masyarakat Pedesaan Melalui Energi Terbarukan. Jakarta: LAKPESDAM-PBNU.

Brunsson, Nils. 1994. Politicization and 'Company'ization-on Institutional Affiliation and Confusion in the Organizational World. Management Accounting Research, Vol. 5, No. 3-4.

Budiman, Arif. 1991. Negara dan Pembangunan: Studi tentang Indonesia dan Korea. Jakarta: Yayasan Padi dan Kapas.

Direktorat Jenderal Ketenagalistrikan, Kementerian Energi dan Sumber Daya Mineral Republik Indonesia. 2018. Laporan Kinerja Tahun 2017.

Ellaban Omar, Abu-Rub Haitham, Blaabjerg Frede. 2014. Renewable energy resources: Current status, future prospects and their enabling technology, Renewable and Sustainable Energy Reviews (39): 748-764.

Frederickson, George. 1980. Administrasi Negara Baru. Jakarta: LP3ES.

Ghazali, AM; Ubaid A; Wardhana AR; Masud, I; Mohammad, J; Ma'afi, M; Wahid, M; Budiarto, R. 2017. Fikih Energi Terbarukan - Pandangan dan Respons Islam atas Pembangkit Listrik Tenaga Surya (PLTS). Jakarta: LAKPESDAM-PBNU.

Greenius L., Jagniecki E., dan Thompson K. (2010). Moving Towards Sustainable Community Renewable Energy: A Strategic Approach for
Communities. Tesis: Master of Strategic Leadership towards Sustainability, School of Engineering, Blekinge Institute of Technology, Swedia.

Hikam, Muhammad A.S. 1999. Islam, Demokratisasi \& Pemberdayaan Civil Society. Jakarta: Erlangga.

Howlett, Michael dan Ramesh, M. 1995. Studying Public Policy Subsyter. Oxford: Oxford University Press.

http://www.iea.org/topics/renewables/, diakses pada 1 Juni 2016.

Intergovermental Panel on Climate Change / IPCC. 2014. Climate Change 2014 Synthesis Report Summary for Policymakers.

International Renewable Energy Agency / IRENA. 2009. Statute of The International Renewable Energy Agency (IRENA).

International Energy Agency. 2018. CO2 emissions from fuel combustion - Highlights, dokumen teknis.

Shoaib A dan Ariaratman S (2016). A Study of Socioeconomic Impacts of Renewable Energy Projects in Afghanistan. Procedia Engineering 145: 995-1003.

Badan Pusat Statistik. 2018. Statistik Indonesia 2018. Jakarta.

Kementerian Energi dan Sumber Daya Mineral Republik Indonesia. 2018. Booklet \#EnergiBerkeadilan - 4 Tahun Kinerja Hingga Kuartal III 2018. Jakarta.

Mas'oed, Mochtar. 2003. Politik, Birokrasi dan Pembangunan. Yogyakarta: Pustaka Pelajar.

Modi, V; McDade, S; Lallement, D; dan Saghir, J. 2005. Energy and the Millennium Development Goals. New York: Energy Sector Management Assistance Programme, UNDP, UN Millennium Project, and World Bank.

Osborne, David \& Ted Gaebler. 1995. Mewirausahakan Birokrasi. Jakarta: Pustaka Binaman Pressindo.

Pemerintah Republik Indonesia. 2014. Peraturan Pemerintah Republik Indonesia Nomor 79 Tahun 2014 tentang Kebijakan Energi Nasional, Jakarta.

Pierre, Jon and B. Guy Peters. 2000. Governance, Politics and the State. Houndmilss: Macmillan Press LTD.

REN21. 2010. Renewables 2010 Global Status Report.

Rinanda, AR. 2018. Analisis Ekonomi, Pencapaian Target Penurunan Emisi Gas Rumah Kaca, dan Dampak Terhadap Harapan Hidup atas Pemanfaatan Energi Terbarukan di Provinsi Jawa Tengah. Tesis: Magister Teknologi untuk Pengembangan Berkelanjutan, Program Studi IImu Lingkungan, Sekolah Pascasarjana Universitas Gadjah Mada.

Santoso, Purwo (ed). 2003. Pembaharuan Desa secara Partisipatif. Yogyakarta: Pustaka Pelajar.

Wardhana, AR. 2018. Analisis Keberlanjutan Pembangkit Listrik Tenaga Surya dengan Metode Analytical Hierarchy Process. Tesis: Magister Teknologi untuk Pembangunan Berkelanjutan, Program Studi IImu Lingkungan, Sekolah Pascasarjana Universitas Gadjah Mada.

Wardhana, AR; Rakhmatulloh, S; Ma'rifatullah, WH. 2018. Latar Belakang Pendirian SEAD-initiative. 